\title{
A Lucid Key to the Common Species of Phytophthora
}

\author{
Jean Beagle Ristaino, Department of Plant Pathology, North Carolina State University, Raleigh, NC 27695
}

\begin{abstract}
Ristaino, J. B. 2012. A lucid key to the common species of Phytophthora. Plant Dis. 96:897-903.

The Key to the Common Phytophthora species (Lucid v 3.4) is a matrix-based computerized identification key and includes important morphological and molecular characters that are useful for identification of 55 common species of Phytophthora. A set of 20 features are used to make a correct species identification. Once a culture is obtained, the user enters responses to known character state options into Lucid Player, and the correct species is identified. Illustrations of each character state for a feature are included in the key. The main morphological features included in the key are: asexual structures, sexual structures, and chlamydospore, hyphae, and cultural characteristics. The user can read an illustrated "Fact Sheet" on each species that in-

range, and relevant references. A cross-linked glossary of terminology is included in each fact sheet. In addition, a DNA search function that contains a simple search of internal transcribed spacer (ITS) and Barcode of Life (BOL, $5^{\prime}$ end of the cox 1 gene) sequences for each species can be queried. The key was created to provide teachers, diagnosticians, and regulatory personnel with easily accessible tools to distinguish common species in the genus Phytophthora based on a number of important morphological and molecular characteristics. The key is available for purchase from APS PRESS and should provide another useful tool for the identification of members of this destructive group of Oomycete plant pathogens.
\end{abstract} cludes pictures of morphological characters, disease symptoms, host
The genus Phytophthora encompasses more than 100 species, and identification of new species is currently expanding at rapid rates $(4,6,8)$. Phytophthora species are diploid, algae-like Oomycetes in the Kingdom Stramenopila (13). Phytophthora are not true fungi, but are "fungus-like" organisms and are more closely related to brown algae than fungi. Many species descriptions have been based on morphological characters that require an expert to observe and discriminate. Regulatory officials who wish to safeguard against quarantine organisms at the ports of entry, to survey for newly established locations, or who wish to make rapid diagnoses in high threat situations need accurate morphological and molecular methods to identify species. Early detection, accurate identification, and the ability to trace pathogens back to their source and eliminate them are the ultimate goals to reduce invasive species such as Phytophthora.

Phytophthora species are responsible for devastating diseases on a wide range of host crops, natural vegetation, and forestry worldwide (9). The genus Phytophthora contains many destructive plant pathogens with great impact on agriculture (e.g., $P$. infestans, potato late blight), floriculture (e.g., P. ramorum, sudden oak death), and whole ecosystems (e.g., P. cinnamomi in Australia). They represent a significant and emerging biosecurity threat, in large part due to increases in plant movement via international trade (5). $P$. infestans exemplifies this threat; it was the first species in the genus described and left a path of devastation on potato in its wake in the United States, Ireland, and Europe in the nineteenth century (1). The potential for the emergence of new pathogens through

Corresponding author: Jean Beagle Ristaino,

E-mail: Jean_Ristaino@ncsu.edu

* The $\boldsymbol{e}$-Xtra logo stands for "electronic extra" and indicates that a supplemental table is included in the online edition.

Accepted for publication 12 December 2011.

http://dx.doi.org/10.1094/PDIS-08-11-0636

(C) 2012 The American Phytopathological Society hybridization, global migration, and accidental release due to expanding agricultural activities and trade, as well as increased concerns about agroterrorism, underscore the importance of developing easily accessible diagnostic tools that allow identification of the major Phytophthora species using both morphology and molecular methods. In North Carolina, several endemic species of Phytophthora threaten agricultural crops yearly. The list includes $P$. infestans on potato and tomato, $P$. capsici on pepper, $P$. cinnamomi on Frasier fir and ornamental crops, $P$. nicotianae on tobacco, and $P$. fragariae on strawberry, among others. Ornamental hosts can be infected by multiple species, making diagnosis difficult. In California, at least 17 common species are routinely identified in diagnostic clinics (C. Blomquist, personal communication).

Traditionally, baiting has been used to detect Phytophthora spp. in soil and water $(9,19)$. Bait materials most often used are Rhododendron leaves and lupine seeds. Isolates are then recovered from infected tissue on selective media. Once a culture is obtained, classical morphology and growth characteristics are used for correct identification of the species $(27,33)$. Classical morphological identification relies on specific taxonomical expertise by a trained scientist. Regulatory guidelines for identification of more notorious species, such as $P$. ramorum, require isolation of a pure culture, morphological identification, and molecular diagnostic tests to confirm identification by a laboratory certified to run the polymerase chain reaction (PCR) assays (30).

Grace Waterhouse, a British mycologist, was an expert in the identification of Phytophthora species and was an authority on the genus (26,32-37). She trained with Elizabeth Blackwell in the 1920s at Royal Holloway College in the UK. Blackwell herself was also a pioneer in early Phytophthora taxonomy (2). Waterhouse gathered together a large collection of Phytophthora cultures and published a compilation of species descriptions from original papers. The well-authenticated and useable dichotomous keys to species in the genus Phytophthora that she developed are still in use today (33). Her meticulous work was based on careful observation of the morphological characteristics of the pathogen including sporangia, sexual reproductive organs, chlamydospores, and hyphal and cultural characteristics. Prior to these keys, others, including 
Leonian (20), and Tucker $(28,29)$, had also developed dichotomous keys to the species.

Jean Stamps and colleagues transformed Waterhouse's dichotomous keys into a more easily used tabular format $(22,37)$ in the 1970s. Ho developed a regionally specialized dichotomous key to Phytophthora species in Taiwan in the 1980s $(14,15)$. The book Phytophthora Diseases Worldwide by Erwin and Ribeiro (9), published in the late 1990s, remains a highly useful reference for techniques and morphological and bibliographic information on Phytophthora species descriptions through the 1990s. Gallegly (10) and Gallegly and Hong (11) recently developed a simplified dichotomous key for identifying Phytophthora species by morphology. They also include single-strand conformational polymorphism (SSCP) analysis as a means to differentiate species by DNA fingerprints (17).

Sequence-based methods have been developed for identification and detection of Phytophthora spp. The most widely studied genes are the ribosomal genes and the introns associated with them (ITS: internal transcribed spacer regions) (38). Based upon these sequences, 10 clades in the genus Phytophthora were described (7). Others have studied the same or additional nuclear and mitochondrial genes, and sequence analysis of several genes showed a similar relatedness among the different Phytophthora species $(3,18,21,25)$. Kang and colleagues developed the internet-based Phytophthora database and used both nuclear ITS sequences for identification of Phytophthora species and other genes for phylogenetic analysis $(16,23)$. More recently, Robideau et al. (24) published on the usefulness of the DNA barcoding region of the cox 1 gene for identification of Phytophthora.

Sequence-based identification of Phytophthora species is now widely used, and identification using online tools such as GenBank, the Phytophthora database, or Phytophthora-ID have been developed $(12,23)$. The pitfalls of sequence-based identifications have been recently reviewed (16). Species identification cannot rely solely on sequence-based identification, since some of the sequence data present in GenBank and elsewhere may not have been submitted for morphologically well-characterized Phytophthora species.

An easy-to-use method of identification for the common Phytophthora species is needed that combines both traditional morphology and DNA sequences. Such an identification tool will be useful to the research, teaching, and regulatory community that works to mitigate Phytophthora diseases in the field. With this goal in mind, this key was developed. Also, diagnostic tools that are readily transportable to developing countries in areas that are remote and lack internet access and that do not rely solely on expensive DNA sequencing are needed in addition to large internetdriven databases (23). The Lucid key described herein can be installed and run from a CD rom drive on a laptop PC.

\section{Materials and Methods}

Isolates used. Isolates of the Phytophthora species used to develop the key were collected from experts in the field who are noted for their research on a given Phytophthora species. Many of the isolates used in this key were the same as those used in the key developed by Gallegly and Hong (11) and generously shared by these and many researchers with the permission of the originator of the cultures. Isolates were deposited into collections at ATCC, CABI Biosciences (IMI), the World Oomycete Collection (WPC), or the Centraalbureau voor Schimmelcultures, the Netherlands (CBS). GenBank accession numbers are provided for the ITS and BOL regions sequenced from the isolates and for those sequenced by other Phytophthora researchers(Supplemental Table 1). The host and geographic origin of the isolates is also provided.

The Lucid Key. The Key to the Common Phytophthora species (Lucid v 3.4) is a matrix-based identification key and includes a compilation of important morphological characters that are useful for identification of 55 species of Phytophthora. A variety of source material was used to develop the key, including previously published identification keys $(9,11,22,27,33)$. Waterhouse grouped

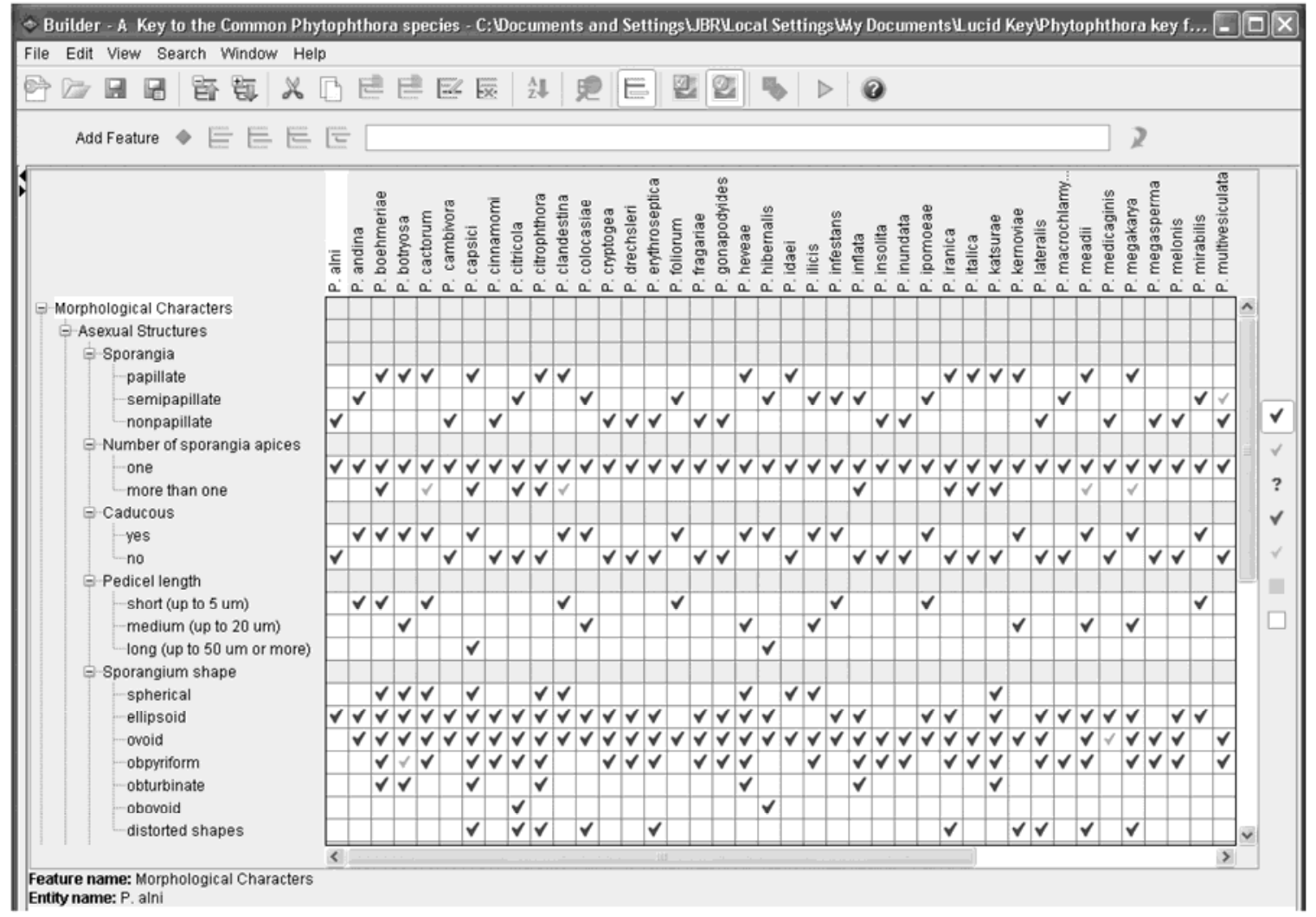

Fig. 1. Matrix spreadsheet used to score character states for a given Phytophthora species in Lucid Builder. The spreadsheet scoring system in Lucid Builder allows 7 score types (vertical icons - right side) including: absent, present, rarely present, uncertain, present by misinterpretation, present by misinterpretation and rare or not scored options to be programmed. 
Phytophthora species based on sporangial characteristics (nonpapillate, semipapillate, or papillate), reproductive behavior (inbreeding [homothallic] or outbreeding [heterothallic]), and the form of the antheridium (amphigynous or paragynous). Cooke et al. (7) found that although Waterhouse's groups do not represent phylogenetic assemblages based on ITS sequence, the criteria are useful for traditional morphospecies identification. We have included many morphological features from the Waterhouse and Stamps keys that are easy to score, particularly those used in the matrix-based key of Stamps et al. (27) in this key. We also used character state measurements from other published sources including Erwin and Ribiero's book (9) and Gallegly and Hong's dichotomous key (11). In addition, we sequenced DNA from select genes and spacers (ITS and BOL regions) of well characterized isolates, and these were also included in a DNA search query in the key to confirm the morphological identification. Fact Sheet Fusion Builder was used to develop informational "Fact Sheets" that include pictures of important character states for each species and symptoms of disease.

Lucid Builder. Lucid Builder (LucidCentral.org, Queensland, Australia) was used to develop the backbone of the key. A set of features and character states were chosen and scored into Lucid Builder that allow the user to make a correct identification of an unknown Phytophthora species. The matrix or spreadsheet scoring method was used to enter data into the key (Fig. 1). The main features included in the key are: asexual structures (sporangium type, number of apices, caducity, pedicel length, sporangium shape, sporangium base, sporangium length:breadth ratio, sporangium length, and sporangiophore features), sexual structures (reproductive behavior [homothallic or heterothallic], antheridia type, oogonia size and features, oospore size and features), chlamydospores, hyphae and cultural growth habit, growth rate, and temperature optimum.

Lucid Player. Lucid Player is used to make a species identification. First, a user must have a culture of the species of interest. A link to protocols that are useful to isolate and grow Phytophthora species and produce the morphological characters needed to identify a given species is provided on the home page (Fig. 2). In addition, references and protocols for DNA isolation and molecular identification are given. Features of the specimen are observed microscopically, and measurements of sporangia, oogonia, and oospores should be completed before identification with the key is undertaken.

When the key is opened, four windows are displayed (Fig. 3). The top left window contains 20 characters and their states. To see the states, the user clicks on the plus (+) symbol beside the feature text (asexual structures, sexual structures, chlamydospores, hyphae, and culture growth, etc.). The states can be selected by clicking the thumbnail image pictures or by checking the box when thumbnails are not showing on the left side of the feature text. Selections will appear in the lower left window as records of the user's choices are made. When the user has finished with a feature, the minus (-) symbol can be clicked to hide the choices. This will save time and compress the window view and enable the user to avoid scrolling down to the bottom of the window to find more features.

The user enters responses to known character states of features into Lucid Player, and the correct species is narrowed down and ultimately identified. Illustrations of character states of each feature are included where applicable, and a glossary of terms to guide the user is included and cross linked among fact sheets. Character states of a given isolate are checked as present or absent in the key (Fig. 3, upper left window). The species with the states of interest are selected (upper right window), while others are eliminated (lower boxes) by this process. All character states need not be entered to make a correct identification.

In the top right-hand window is a list of 55 Phytophthora species that are contained within the key. As further selections are made, some species will be discarded from this list. The discarded species are displayed in the lower right-hand window. The aim is to reduce the number of possible Phytophthora species in the top right window to one or a few.

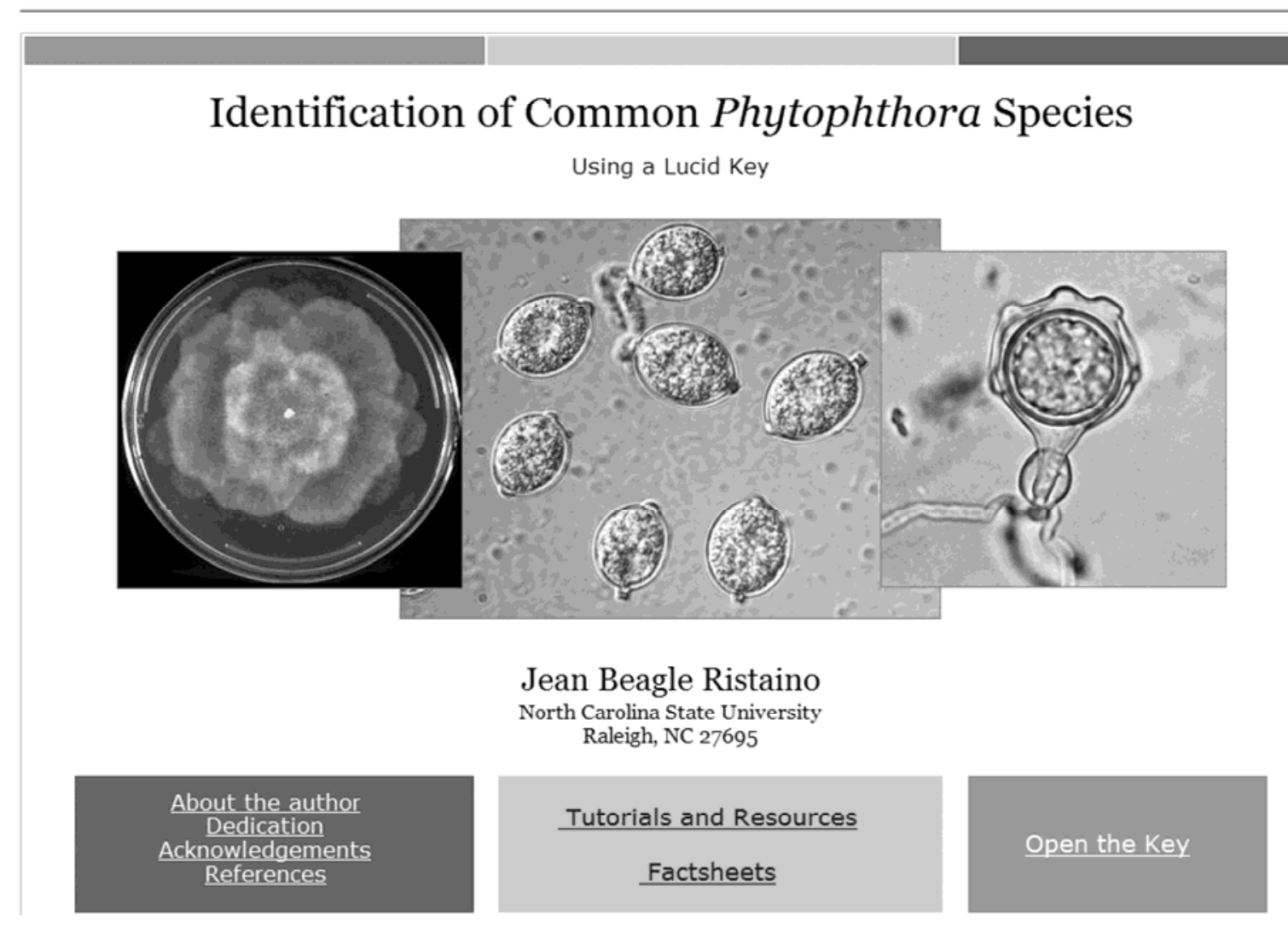

Fig. 2. Home page of the key contains information about the author, a dedication page, acknowledgments, references, links to tutorials and resources, fact sheets, and a link to open the key. 
Lucid Player also has a shortcut feature that narrows down the list of features and states needed to make a correct identification. The shortcut icon is found in the icon tool bar at the top of the Lucid Player page (Fig. 4). For example, selecting "chlamydospores present" narrows the list of species for identification to only those with chlamydospores, including $P$. ramorum. The shortcut feature can be found by toggling on the tool bar at the top of the screen (Fig. 3). A mouse-over function identifies the function of each icon on the tool bar.

\section{Tips for Proper Identification}

You don't have to select options for all feature states, and it doesn't matter what order you answer them in. If several new features are offered, skip to the feature that seems most relevant to your isolate. If you don't think any of the options fits your case, skip the question. If you run out of questions, you may want to come back to the ones you missed.

You can choose more than one state per feature. Multiple states of a feature may apply to your isolate. For example, sporangial shape may be variable or ovoid ellipsoid, etc. If so, select all the states that apply to your specimen. If there is uncertainty about a feature size, for example a sporangial size feature $(<20$ or 20 to 30 $\mu \mathrm{m}$ ), then select both. Measurements of spore sizes (sporangial, oogonium, or oospores) are not key feature states that will separate any given species from the rest in the key.

Use the "Best", "Next Best", and "Prune Redundant Features" icons in the key tool bar to help you move through the key efficiently. The "Best" feature will suggest features that help you split the remaining Phytophthora species. The "Prune" feature will remove any redundant features that no longer remove any species from the remaining list. The two buttons "Best" and "Prune" can be used alternately, one after the other. Alternatively, you can automate these features via the Features...Automate menu option.

It is easy to undo a selection. Just click the ticked box again, in either of the left-hand windows.
Keep selecting options until you have only one taxon remaining, or until you run out of features you can answer. If only a few taxa remain, try viewing the fact sheet or images for a few suspected Phytophthora species. If there are more than a few, look back over the key to see if there are additional features you could have answered or a feature you accidentally checked off. Alternatively, the "Differences" tool near the right-hand end of the tool bar can be used to get a list of all the questions where scores for the remaining taxa differ. Click a feature shown in the Differences window, and the states scored for each remaining Phytophthora species will be displayed.

You can turn on and off thumbnail options by toggle buttons: "Feature Thumbnails" and "Entity (Phytophthora) Thumbnails". You may also change the feature state view from a vertical list to a gallery view where all images will be shown horizontally via the Features.Display menu option.

If you end up with no Phytophthora species remaining, look back over your selections and undo any you were not sure about, or that don't seem essential to describe the isolate. If you still have no species remaining, you may have a novel species or you may have a species that is not included in the key. In order to discern the difference, further work will be necessary using other published descriptions of new species or online databases that include additional species of Phytophthora. Sequencing the ITS and BOL regions will also be a critical step in discerning the genetic relatedness of the unknown species to other published species.

You can restart the key by using the restart icon at the far lefthand end of the tool bar.

You can change the size of the windows by dragging their inside edges. You may want to make the left window wider, to read the longer state descriptions without having to scroll across. You can drag it back again when you need to read the full names of remaining species.

Fact sheets. Fact Sheet Fusion builder was used to develop a species description page in html for each Phytophthora species that

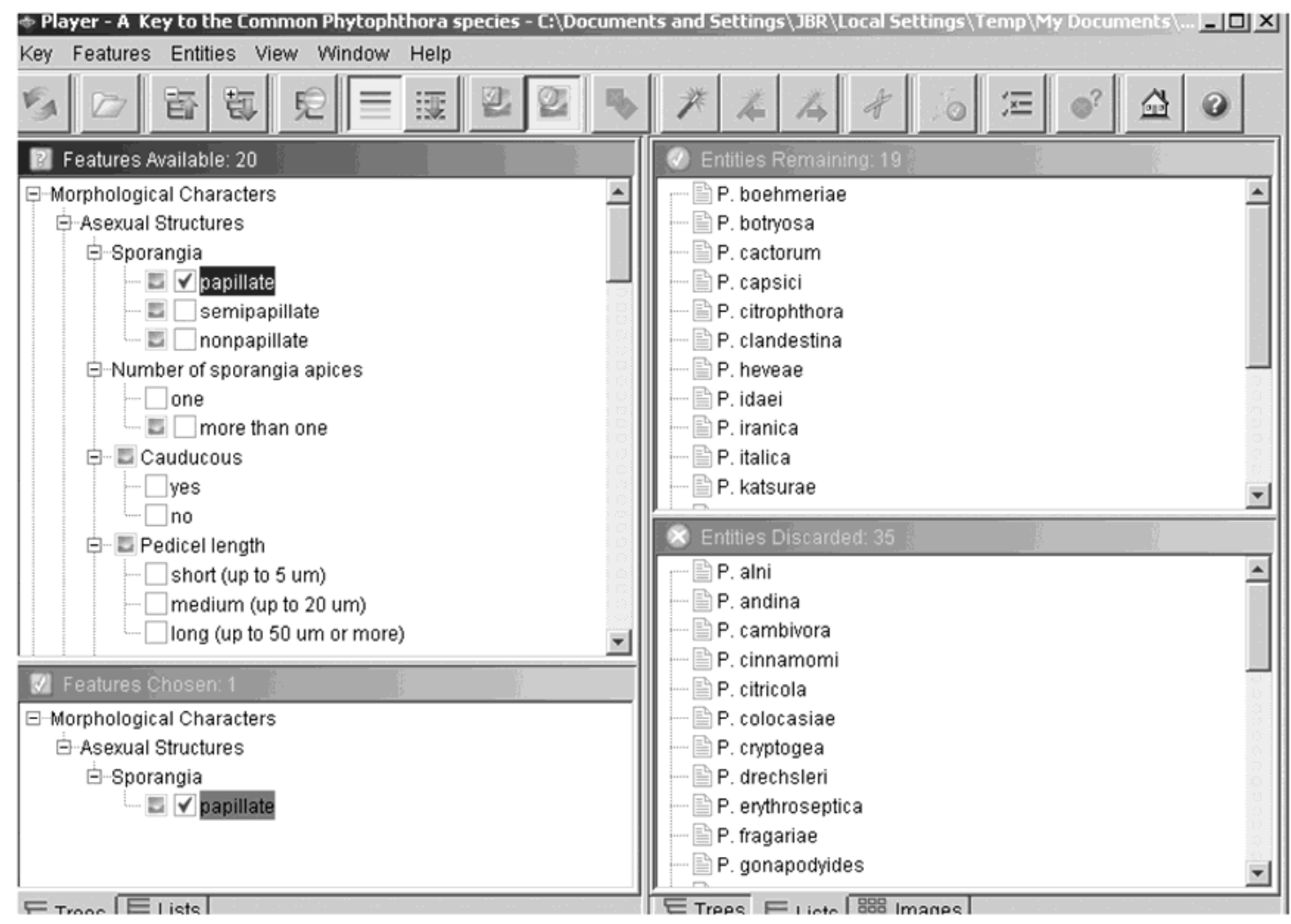

Fig. 3. Lucid Player is used to make a species identification. First, a user must have a culture of the species of interest. Features of the specimen are examined, and known character states of a feature are entered into the key (upper left window). By a process of elimination, species with the character states of interest are selected (upper right window) while others are eliminated (lower right window). 
is linked to Lucid Player. The user can read an illustrated fact sheet on each species of interest by simply toggling on the fact sheet html icon. A cross-linked glossary of terminology is included in the fact sheets and can also be reviewed in an alphabetical glossary. Each fact sheet (Fig. 5) includes an introduction that describes the first reports and nomenclature of each Phytophthora species, cultural characteristics, reproductive structures (sporangia, hyphae, chlamydospore, oogonia, oospore characters), host range and distribution, symptoms, and references. An internet connection is not needed to access the fact sheets. They can also be viewed from the home page of the key.

Items such as the feature states and Phytophthora species in the key have pictures and/or html fact sheets attached to them. They are displayed as an icon or a thumbnail to the left of the item.

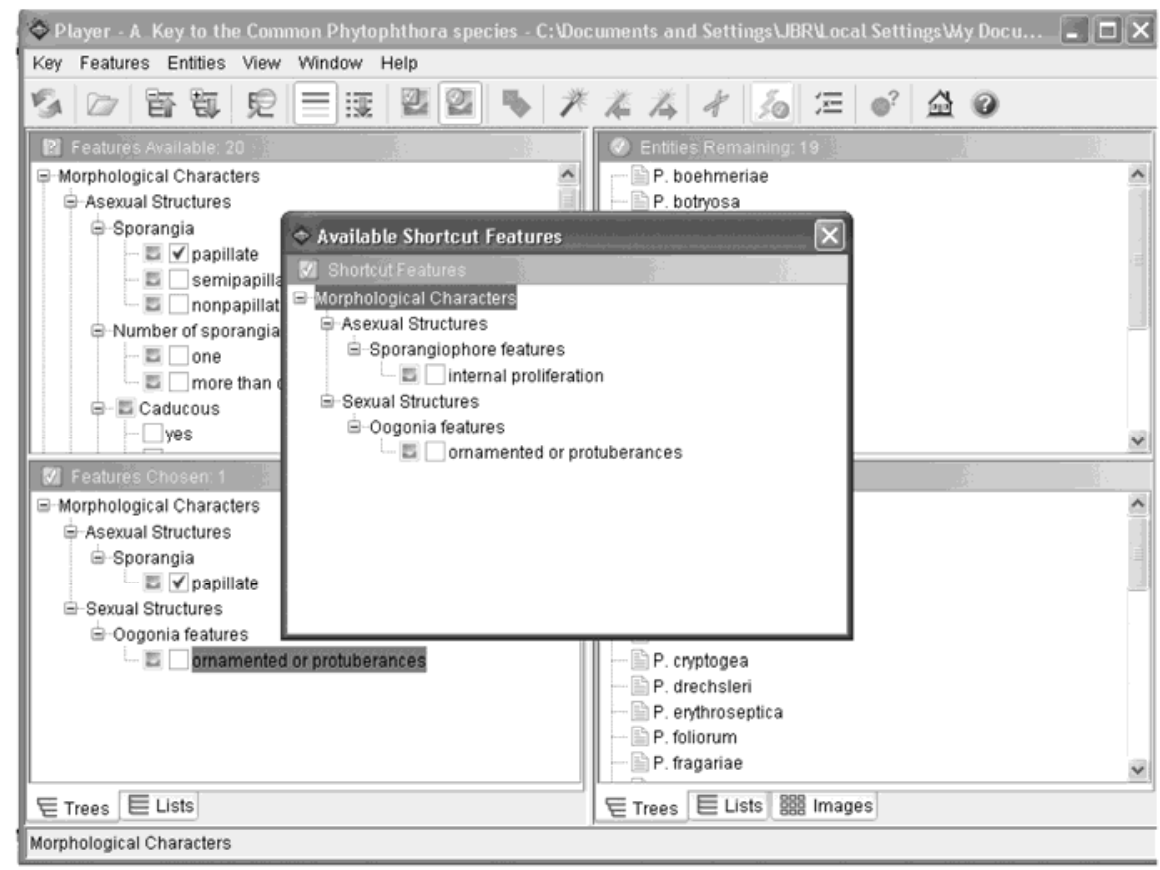

Fig. 4. Lucid Player also has a shortcut feature that narrows the list of character states needed to make a correct identification of the remaining species of interest after a few character states have been selected. The icon tool bar at the top of Lucid Player contains a mouse-over feature that describes the function of each icon including the shortcut icon, the home page icon, and the Lucid help page.

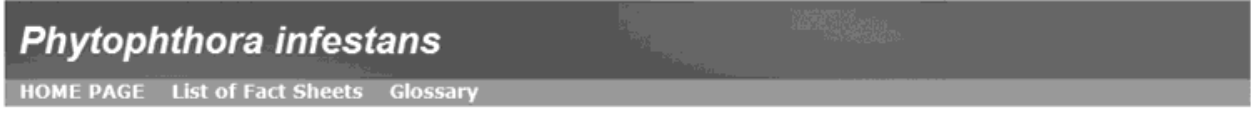

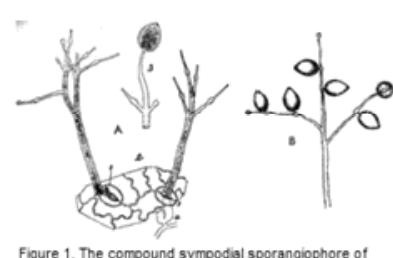

Figure 1. The compound sympodial sporangiophore of
Phytoonthora intestans (Reproduced, by permission of Cat Phytophehors infestans. (Reproduced, by permission of CAB

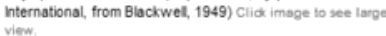

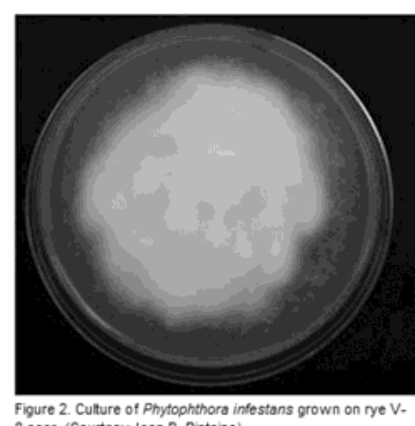

Figure 2. Culture of Phytophehora intest
8 agar. (Courtesy Jean B. Ristaino)
Introduction

Phytophthora infestans (Mont.) de Bary (1876)

Phytophthora infestans was first described by C. Montagne in France under the name Botrytis infestans and by the Reverend M. J. Berkeley in 1846 (Berkeley, 1846; Montagne, 1846 ). The pathogen caused the Irish potato famine. Morren had observed the disease in Belgium in 1844 , called it Botrytis devastatrix, and presented a paper to the Royal Society of Lille (Morren, 1844). Libert had also called the pathogen Botrytis devastatrix Lib. 1845 of Lille (Morren, 1844). Libert had also called the pathogen Botrytis devastatnx Lib. 1845 (alternate spelling vastatrix or devastrix), but Berkeley chose to use the species name Botrytis infestans. Unger and Caspary considered it in the genus Peronospora (Caspary, 1852; Unger, 1847). de Bary accepted this opinion in 1863 and then, in 1876, renamed the species Phytophthora infestans based on sporangial development and sporangiophore characteristics (de Bary, 1876). Botrytis vastatrix is an illegitimate superfluous name; Liber published it as a replacement name for Botrytis farinosa $\mathrm{Fr} . \mathrm{Fr}$. (1829) (=Peronospora farinosa), but this refers to a different species than $P$. infestans (Cline et al. 2008) Waterhouse (1963), Stamps (1984), and Stamps et al. (1990) place $P$. infestans as a group IV species (Fig. 1 )

\section{Cultural Characteristics}

Cultures of $P$. infestans are slow growing. The mycelium is white and fluffy (Fig. 2). The minimum temperature for growth is $4^{\circ} \mathrm{C}$, the optimum temperature for growth is $20^{\circ} \mathrm{C}$, and the maximum temperature for growth is $26^{\circ} \mathrm{C}$. There is no colony growth at temperatures above $26^{\circ} \mathrm{C}$

Reproductive Structures

\section{Asexual Structures}

Sporangiophores:

Sporangiophores are clearly differentiated from the mycelium and are erect, branching, compound, and sympodial, with a small characteristic swelling at the base of each branch (Fig. 1).

Fig. 5. Fact Sheet Fusion builder was used to develop an html formatted species description page for each Phytophthora species. Fact sheets can be viewed by selecting the page icon next to each species in the entity list in Lucid Player. A fact sheet for Phytophthora infestans is shown. 
Clicking the fact sheet icon will open the attached fact sheet page. Clicking on the image icon or image thumbnail will open a large version of the image for some of the images in the fact sheets (indicated by "click here for larger image").

DNA sequence search function. In addition, if a DNA sequence is available for an isolate, a sequence search of the ITS and BOL region sequences can be used directly in the key to identify species (Fig. 6). A complete species table that lists isolate numbers, sources, and GenBank accession numbers is included. Protocols for ITS and BOL PCR are included in the key and on the home page in addition to a diagram of the region to be sequenced and primer sequences.

Multimedia tips. Web pages such as fact sheets attached to items in the key may be considered pop-ups by certain browsers (such as Internet Explorer) when clicked on by users. If your browser blocks these fact sheets as pop-ups, in your browser's internet settings you should allow pop-ups for this Lucid tool. Additionally, Internet Explorer may block "active content" on web pages or the fact sheets of interactive keys. To allow active content, in Internet Explorer, under Tools, Internet Options, Advanced tab, Security category, the box next to the setting: "Allow active content to run in files on My Computer" should be checked. Note that the key does not require internet access to operate and can be used directly from a laptop in the field.

\section{Accessing the Lucid Player Help and Homepage Tutorial}

The Lucid Player has help available that explains all the functionality of the key. To access the help, select the help icon (?) on the tool bar or access it via the help menu. It is recommended that you scan through the help menu before beginning. The keys homepage contains a voiceover power point that also explains the functionality of the key (Fig. 2). The keys home icon links to the key tutorial. Protocols that are useful for isolating the pathogen, producing morphological structures and PCR can be found at the home page link.

Beta testing and validation of the key. Cheryl Blomquist, California Department of Food and Agriculture; Carrie Harmon,
University of Florida and coordinator of the Southern Plant Diagnostic Network; and Tom Creswell, Purdue University provided comments and beta tested the key in their respective diagnostic clinics. Terrance Walters and Julie Sher, USDA-APHIS, also provided useful reviews of the key. The key was also beta tested in a Phytophthora diagnostic workshop funded by USAID Hort Crsp that was held in San Jose, Costa Rica in June 2010. The ambitious agenda for the workshop ranged from isolation of Phytophthora from plant samples and water to morphological and molecular diagnostics. At the beginning of the week, 24 students were paired and given unknown cultures of Phytophthora (culture identity known to the instructors). They were given a detailed protocols workbook and were asked to run a series of experiments during the week to make a correct species identification. The students made slides and used the microscope to document morphological characters of their unknown isolates. They were also given temperature optimum and growth information in order to make an identification with the key. The Phytophthora key was installed in a computer laboratory at the Universidad de Costa Rica, and students used the key to make a correct species identification. Sequence-based methods were also taught, including restriction fragment length polymorphism (RFLP) PCR of ITS DNA, and the use of ITS and BOL sequences, and students queried the Phytophthora database with sequence data. The later part of the workshop included real-time PCR with an all Phytophthora set of primers followed by Padlock probes (PLPs) to identify their unknown cultures (31). Eleven of the 12 student teams identified their unknown cultures correctly using morphology and the Lucid Key.

\section{Conclusions}

Use of the Key to the Common Phytophthora species should enhance the ability of diagnosticians, regulatory personnel, researchers, and teachers to quickly identify species in the genus using a range of morphological characters and ITS or cox 1 DNA sequences. The key is available for purchase from APS PRESS and can be loaded onto a PC using a CD rom drive. The key contains the most commonly encountered species and is not meant to be inclu-

\section{Barcode of Life Sequence Search}

Use the PCR protocol in the DNA methods section to amplify the $5^{\prime}$ end of the mitochondrial cox 1 gene (BOL, Barcode of Life Region) to identify Phytophthora species. Use primers FM80RC and FM85 to amplify a portion of the cox 1 gene.

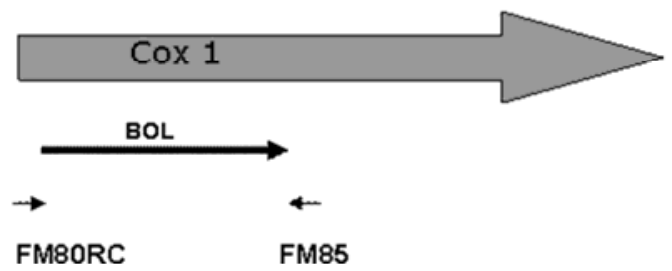

Search the database for a match by entering either ITS or BOL sequences Search 
sive of all recently described species. There are currently well over 90 species described in the genus. It is hoped that additional modules can be added over time to accommodate newly described species with the support of the Phytophthora research community and the appropriate level of funding.

\section{Acknowledgments}

Charles Woloshuk served as editor for the project for APS PRESS. Thanks to Julia Hu, postdoctoral researcher, and former undergraduate Marion Haege, for assistance with the photography, DNA sequencing and editing, and to Elaine Medowar for preparation of template fact sheets and acquiring copyright permission for many images. Appreciation is expressed to P. Bonants, D. Cooke, M. Gallegly, C. Hong, and Matt Ryan for sharing many of their cultures and/or DNA of well-identified species. Many others have donated cultures and or sequence data including Mike Benson, Clive Brasier, Barbara Christ, Mike Coffey, Louise Cooke, Margery Daughtrey, Ken Deahl, John Duniway, D. Ershad, Tom Evans, Greg Forbes, William Fry, Jim Graham, Nancy Gregory, Francine Govers, Nik Grünwald, Phil Hamm, Joe Hancock, Evert Hansen, Hans Hohl, Kelly Ivors, Virginie McFegue, John Menge, Bob Milholland, John Mircetich, Ricardo Oliva, Mary Palm, Dave Rizzo, P. Rose, S. Sawant, David Shew, Paul Tooley, Peter Tsao, Brett Tyler, Janice Uchida, Greg Weidemann, Rob Wick, Wayne Wilcox, and X. B. Yang. Initial funding for the key was provided by Gordon Gordh, USDA APHIS. Additional funding was provided by an NSF REU supplement and USAID Hort Crsp project that allowed further beta testing and completion of the key. Thanks to Alexander Krings, Department of Plant Biology, NC State, for assistance with the DNA sequence search function. Thanks to the Australian-based Lucid development team including Matt Taylor for technical assistance. Thanks to Steve Kronmiller and Sue Figueroa from APS PRESS for final editing and deployment of the key.

\section{Literature Cited}

1. Berkeley, M. J. 1846. Observations, botanical and physiological on the potato murrain. J. Hortic. Soc. London 1:9-34.

2. Blackwell, E. M. 1949. Terminology in Phytophthora. Mycol. Pap. 30, Commonw. Mycol. Inst., Kew, Surrey, England.

3. Blair, J. E., Coffey, M. D., Park, S.-Y., Geiser, D. M., and Kang, S. 2008. A multi-locus phylogeny for Phytophthora utilizing markers derived from complete genome sequences. Fungal Genet. Biol. 45:266-277.

4. Brasier, C. 2007. Phytophthora biodiversity: How many Phytophthora species are there? Pages 101-115 in: Proc. Fourth Meeting Int. Union For. Res. Organ. (IUFRO) Working Party S07.02.09: Phytophthoras in Forest and Natural Ecosystems. E. M. Goheen and S. J. Frankel, eds. U.S. Dep. Agric. For. Serv., Pacific Southwest Research Station, Monterey, CA.

5. Brasier, C. M. 2008. The biosecurity threat to the UK and the global environment from international trade in plants. Plant Pathol. DOI.111/j.1365-3059.2008.01886.

6. Cline, E. T., Farr, D. F., and Rossman, A. Y. 2008. A Synopsis of Phytophthora with accurate scientific names, host range, and geographic distribution. Plant Health Progress. Doi:10.1094/PHP-2008-0318-01-RS.

7. Cooke, D. E. L., Drenth, A., Duncan, J. M., Wagels, G., and Brasier, C. M. 2000. A molecular phylogeny of Phytophthora and related Oomycetes. Fungal Genet. Biol. 30:17-32.

8. Ersek, T., and Ribiero, O. K. 2010. Mini-review: An annotated list of new Phytophthora species described post 1996. Acta. Phytopathol. Entomol. Hungar. 45:251-266.

9. Erwin, D. C., and Ribeiro, O. K. 1996. Phytophthora Diseases Worldwide. American Phytopathological Society, St. Paul, MN.

10. Gallegly, M. 1983. New criteria for classifying Phytophthora and critique of existing approaches. Pages 167-172 in: Phytophthora: Its Biology, Taxonomy, Ecology and Pathology. D. C. Erwin, ed. American Phytopatholical Society, St Paul, MN.

11. Gallegly, M., and Hong, C. 2008. Phytophthora: Identifying Species by Morphology and DNA Fingerprints. American Phytopathological Society, St. Paul, MN.

12. Grünwald, N. L., Martin, F., Larsen, M., Sullivan, C., Press, C., Coffey, M., Hansen, E., and Parke, J. 2011. Phytophthora-id.org: A sequence-based Phytophthora identification tool. Plant Dis. 95:337-342.

13. Gunderson, J. H., Elwood, H., Ingold, A., Kindle, K., and Sogin, M. L. 1987. Phylogenetic relationships between chlorophytes, chrysophytes, and oomycetes. Proc. Natl. Acad. Sci. 84:5823-5827.

14. Ho, H. H. 1981. Synoptic key to the species of Phytophthora. Mycologia 73:705-714.

15. Ho, H. H., Ann, P. J., and Chang, H. S. 1995. The genus Phytophthora in Taiwan. Inst. Bot., Academia Sinica Monogr. Ser. No. 15, Tapei.

16. Kang, S., Mansfield, M., Park, B., Geiser, D., Coffey, M., and Grünwald, N. J. 2010. The promise and pitfalls of sequence-based identification of plant pathogenic fungi and oomycetes. Phytopathology 100:732-737.
17. Kong, P., Hong, C., Richardson, P. A., and Gallegly, M. E. 2003. Singlestrand-conformation polymorphism of the ribosomal DNA for rapid species differentiation in the genus Phytophthora. Fungal Genet. Biol. 39:238-249.

18. Kroon, L. P. N. M., Bakker, F. T., van den Bosch, G. B. M., Bonants, P. J. M., and Flier, W. G. 2004. Phylogenetic analysis of Phytophthora species based on mitochondrial and nuclear DNA sequences. Fungal Genet. Biol. 41:766-782.

19. Larkin, R. P., Ristaino, J. B., and Campbell, C. L. 1995. Detection and quantification of Phytophthora capsici in soil. Phytopathology 85:10571063.

20. Leonian, L. H. 1934. Identification of Phytophthora species. W.Va. Agric Exp. Stn. Bull. 262

21. Martin, F. N., and. Tooley, P. W. 2003. Phylogenetic relationships among Phytophthora species inferred from sequence analysis of mitochondrially encoded cytochrome oxidase I and II genes. Mycologia 95:269-284.

22. Newhook, F. J., Waterhouse, G. M., and Stamps, D. J. 1978. Tabular key to the species of Phytophthora De Bary. Mycol. Pap. 143. Commonw. Mycol. Inst., Kew, Surrey, England.

23. Park, J., Park, B., Veeraraghavan, N., Jung, K., Lee, Y., Blair, J., Geiser, D., Isard, S., Mansfield, M., Nikolaeva, E., Park, S., Russo, J., Kim, S., Greene, M., Ivors, K., Balci, Y., Peiman, M., Erwin, D. C., Coffey, M. B., Rossman, A., Farr, D., Cline, E., Grünwald, N. J., Luster, D. G., Schrandt, J., Martin F., Ribeiro, O., Makalowska, I., and Kang, S. 2008. Phytophthora Database: A Forensic Database Supporting the Identification and Monitoring of Phytophthora. Plant Dis. 92: 966-972.

24. Robideau, G. P., de Cock, A. W. A. M., Coffey, M. D., Voglmayr, H., Bonants, P. J. M., Ristaino, J. B., Chitty, D., Rintoul, T., Désaulniers, N., Eggertson, Q., Bala, K., Gachon, C. M. M., Smith, M. L., and Lévesque, A. 2011. DNA barcoding of oomycetes with cytochrome c oxidase subunit (COI). Mol. Ecol. Resour. 11:1002-1011.

25. Schena, L., Duncan, J. M., and Cooke, D. E. L. 2008. Development and application of a PCR-based 'molecular tool box' for the identification of Phytophthora species damaging forests and natural ecosystems. Plant Pathol. 57:64-75.

26. Stamps, J., Brady, K., and Ristaino, J. 2007. Grace Marion Waterhouse, (1906 - 1996), Phytophthora systematist and taxonomist. Pages 143-153 in: Pioneering Women in Plant Pathology. J. B. Ristaino, ed. American Phytopathological Society, St Paul, MN.

27. Stamps, D. J., Waterhouse, G. M., Newhook, F. J., and Hall, G. S. 1990 Revised tabular key to the species of Phytophthora de Bary. C.A.B. International Mycological Institute, Mycol. Pap. No. 162. Commonw. Mycol. Inst. Kew Surrey, England.

28. Tucker, C. M. 1931. The taxonomy of the genus Phytophthora de Bary. Univ. Mo. Agric. Exp. Stn. Res. Bull. 153.

29. Tucker, C. M. 1967. The taxonomy of the genus Phytophthora de Bary, Craamer, Wheldon \& Wesley, Stechert-Hafner in Lehre, Codicote, Herts, New York.

30. U.S. Dep. Agric. APHIS. 2007. U.S. Department of Agriculture Animal Plant Health Inspection Service. 2007. Phytophthora ramorum: Quarantine and regulation. Fed. Reg. 72:8585-604.

31. Van Doorn, R., Szemes, M., Bonants, P., Sallas, J., Ortenberg, E., and Schoen, C. D. 2007. Quantitative multiplex detection of plant pathogens using a novel ligation probe-based system coupled with universal, ultra-highthroughput real-time PCR on OpenArrays ${ }^{\mathrm{TM}}$. Bio-Med Central Genomics BMC Genomics 8:276.

32. Waterhouse, G. M. 1956. The genus Phytophthora. Diagnoses (or descriptions) and figures from the original papers. Misc. Publ. 12. Commonw. Mycol. Inst., Kew, Surrey, England.

33. Waterhouse, G. M. 1963. Key to the species of Phytophthora de Bary. Mycol. Pap. 92, Commonw. Mycol. Inst., Kew, Surrey, England

34. Waterhouse, G. M. 1970. The genus Phytophthora. Diagnoses (or descriptions) and figures from the original papers. Mycol. Pap. 122, Commonw. Mycol. Inst., Kew, Surrey, England.

35. Waterhouse, G. M. 1970. Taxonomy in Phytophthora. Phytopathology 60:1141-1143.

36. Waterhouse, G. M., and Blackwell, E. M. 1954. Key to the species of Phytophthora de Bary recorded in the British Isles. Mycol. Pap. 57. Commonw. Mycol. Inst., Kew, Surrey, England.

37. Waterhouse, G. M., Newhook, F. J., and Stamps, D. J. 1983. Present criteria for classification of Phytophthora. Pages 139-147 in: Phytophthora: Its Biology, Taxonomy, Ecology, and Pathology. D. C. Erwin, S. BartnickiGarcia, and P. H. Tsao, eds. American Phytopathological Society, St. Paul $\mathrm{MN}$.

38. White, T. J., Burns, T., Lee, S., and Taylor, J. 1990. Amplification and direct sequencing of fungal ribosomal RNA genes for phylogenetics. Pages 315 322 in: M. A. Innis, D. H. Gelfand, J. J. Sninsky, and T. J. White, eds. PCR Protocols: A Guide to Methods and Applications. Academic Press, San Diego, CA. 